\title{
Scale and Community Structure of Coral Reef Fishes: A Long-Term Study of a Large Artificial Reef
}

\author{
J. C. Ogden ${ }^{1}$ and J. P. Ebersole ${ }^{2}$ \\ ${ }^{1}$ West Indies Laboratory, Fairleigh Dickinson University, P.O. Box 4010, Christiansted, St. Croix, U. S. Virgin Islands 00820 \\ ${ }^{2}$ Department of Biology, University of Massachusetts, Boston, Mass. 02125, USA
}

ABSTRACT: The fish community of a large artificial reef made in 1960 of 800 concrete blocks in a seagrass bed on the south coast of St. John, U.S. Virgin Islands, was studied by comparing a series of visual censuses (1975-1979) with each other and with a 1962 total-poison station collection (Randall, 1963). Discounting the presence of some cryptic species in the poison station that would not normally be seen in visual censuses $(\mathrm{N}=10)$, as well as discounting seagrass-bed residents and roaming species only transient on the reef $(N=13)$, all of the censuses and the poison station (range 31-40 spp.) were found to be similar (Spearman Rank Correlations: all $\mathrm{p}<.01$ ). This stability stands in contrast to the apparent unpredictability reported for smaller artificial and natural reef structures on the Great Barrier Reef (Sale and Dybdahl 1975, 1978; Talbot et al., 1978) which has been attributed to chance factors of recruitment. We interpret our results as evidence for orderly interactions as important factors in the determination of community structure, and suggest that short-term studies of small reefs lack the resolving power to detect this type of evidence.

\section{INTRODUCTION}

A growing number of field studies have been focused on coral reef fishes in an attempt to improve our understanding of the origin and maintenance of the high diversity of these tropical communities (Smith and Tyler, 1972, 1975; Sale, 1977; Talbot et al., 1978; Gladfelter et al., in press). Two general points of view have emerged. Sale $(1975,1977)$ and others (Talbot et al., 1978) working in the Great Barrier Reef suggest that high diversity in coral reef fish communities is maintained by the chance arrival of larval colonists to unpredictably available habitat space. They cite as evidence the unpredictable composition of coral reef fish communities on small natural and artificial structures. This view is countered by work on small structures in the Caribbean and Gulf of California where fish communities were shown to be relatively predictable for particular types of habitat, leading to the conclusion that adaptive responses to habitat, competition and predation lead to the orderly structuring of reef fish communities (Smith, 1973; Smith and Tyler, 1975; Molles, 1978). The species pools in the Caribbean and Gulf of California are substantially smaller than in the tropical Pacific (Goldman and Talbot, 1976) and the relative role of this factor has not yet been assessed.

On a larger structure, Smith (1979) found in the Gulf of Mexico that the fish fauna of a patch reef decimated by a red tide in 1971 was quickly reestablished and showed little change over 3 years thereafter, whereas Brock et al. (1979) working on a large Hawaiian patch reef, compared two complete collections separated by 11 years to find that only $40 \%$ of the total species collected were common to both. Gladfelter et al. (in press) have conducted a study specifically designed to compare Caribbean patch reefs with their Pacific equivalents, taking data in the same manner in both oceans. They report that in the Pacific as well as the Caribbean, reefs of similar structure and location have similar fish faunas.

Artificial reefs have been used extensively to study the development of reef fish communities. Most such studies (Talbot et al., 1978; Molles, 1978) have concerned small structures followed for a relatively short term - at the most several years. We report here on a series of observations on a large artificial reef that extend over 19 years. Its history and some of the manipulations performed on it allow interesting comparisons with the studies conducted on smaller reefs over shorter periods of time. 


\section{MATERIAL AND METHODS}

On 6 April 1960, Randall (1963) constructed an artificial reef of 800 concrete blocks in about $9 \mathrm{~m}$ of water in Little Lameshur Bay (Virgin Islands National Park USA). The reef (Randall Reef) was placed in an area where the bottom is covered with the seagrasses Thalassia testudinum and Syringodium filiforme. The arrangement of the blocks included several arms in the form of tunnels with holes $20 \mathrm{~cm}$ high and $8 \mathrm{~cm}$ wide and the whole reef covered an area of approximately $125 \mathrm{~m}^{2}$. The nearest natural reef is more than $100 \mathrm{~m}$ away.

Randall (1963) made visual censuses of resident fishes on the reef for several years following construction. On 7 August 1962, about 28 months after construction of the reef, it was surrounded by a large net and all fishes present were poisoned with rotenone, collected, counted and weighed. Following this collection the reef remained relatively undisturbed for 13 years. Fish trapping is permitted in the waters of the V.I. National Park and its potential effects on larger reef residents cannot be assessed. As part of a continuing study of reef fish predators, in November 1978 (between the 1978 and 1979 censuses) 2 spotted morays Gymothorax moringa, and 11 purple-mouth morays $G$. vicinus were removed from the reef.

Beginning in May 1975, the reef was visited four times (August 1977; October 1978; July 1979) in order to visually census the fishes present. These censuses were conducted during daylight hours (with the exception of 1975 when both day and night censuses were made) by at least 2 and up to 4 experienced observers. Each observer estimated total fish numbers during census periods of approximately $1 \mathrm{~h}$. Following the census, the observers jointly compiled a master list based on individual censuses. There are difficulties in estimating the numbers of some species, but the arrangement of the reef into isolated arms which could be covered one at a time minimized this problem. For the purposes of some calculations fishes were assigned abundance categories following the method of Gladfelter et al. (in press).

The reef structure has collapsed considerably in the 19 years since it was built and many of the blocks have disappeared below the surface of the sediment (Fig. 1). The reef has a maximum height in a few areas of about $50 \mathrm{~cm}$ but most of it is very close to sediment level, so total reef volume is considerably less than in 1962. The blocks have abundant sponge growth, mostly of encrusting varieties. There are many small coral colonies present averaging about $10 \mathrm{~cm}$ in size. The hydrozoan corals Millepora spp. are also abundant as are the anemones Stoichactis and Bartholomea. In no sense are the blocks overgrown; the outline of individual blocks is easily seen and the sessile invertebrates occur in discrete colonies. The most conspicuous macro-algae are Sargassum spp.

\section{RESULTS}

The census parameters compiled from census data for all years appear in Table 1 . Some species $(N=10)$ from the families Scorpaenidae, Moringuidae, Ophididae, Gobiidae, Xenocongridae and Emmelichthyidae - collected by Randall in 1962 - have been omitted from subsequent censuses and from this analysis because of their cryptic or highly mobile nature. Other families and species excluded from all censuses $(\mathrm{N}=$ 13) because they are seagrass-bed residents, other non-reef dwellers or roaming species are: Lutjanidae (2 $\quad$ spp.), Mullidae (2 $\mathrm{spp}$.), Sparisoma radians (Scaridae), Ostracionidae (2 spp.), Sparidae (1 spp.), Sphyraena barracuda (Sphyraenidae), Scomberomorus regalis (Scombridae), Caranx ruber (Carangidae) and Diodon holocanthus (Diodontidae). In addition, clinid species were lumped in the analysis as they were not

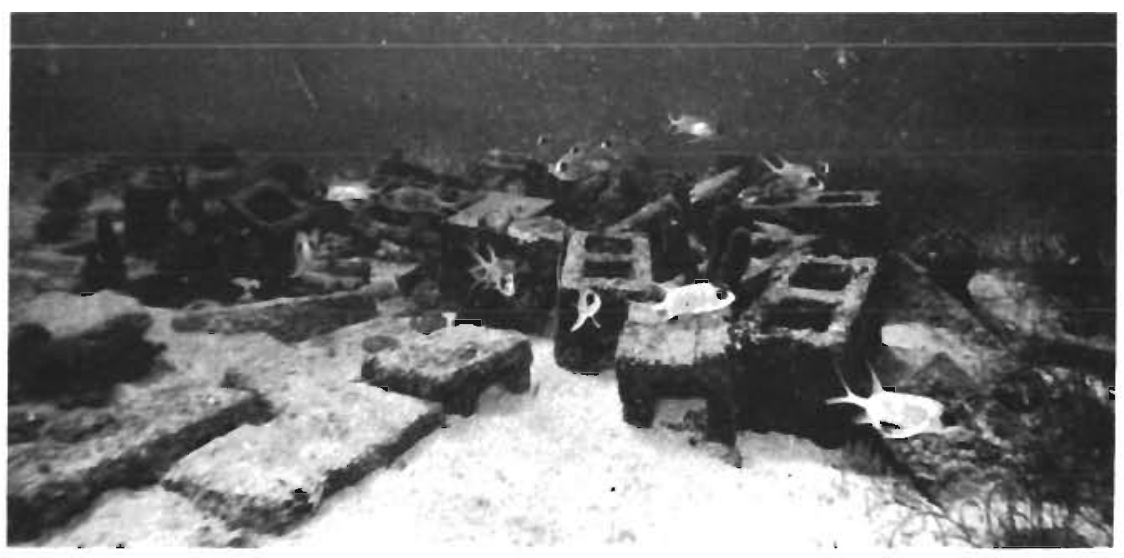

Fig. 1. One arm of Randall Reef in 1979 showing lightly encrusted blocks, many nearly buried by sediment, and several longjaw squirrelfish Holocentrus ascensionis 
Table 1. Compilation of census data from Randall Reef

\begin{tabular}{|c|c|c|c|c|c|c|c|}
\hline Census date & $\begin{array}{l}\text { Number of } \\
\text { species }^{1}\end{array}$ & $\begin{array}{l}\text { Number of } \\
\text { individuals }\end{array}$ & $\begin{array}{l}\text { Number of } \\
\text { families }^{2}\end{array}$ & $\mathrm{H}^{\prime}$ & $\begin{array}{l}\text { Equitability } \\
\qquad\left(\mathrm{J}^{\prime}\right)^{3}\end{array}$ & $\begin{array}{l}\% \text { Turnover from } \\
\text { previous census }\end{array}$ & $\begin{array}{c}\% \text { Change } \\
\text { in total abundance }\end{array}$ \\
\hline 1962 & 39 & 2656 & 14 & 2.4 & & - & - \\
\hline 1972 & 36 & & & & & 23 & 85 \\
\hline 1977 & 31 & 774 & 1 & & & 19 & \\
\hline 1978 & 32 & 1048 & 1 & & & & \\
\hline 1979 & 40 & 1346 & 14 & 3.14 & & 21 & 25 \\
\hline \multicolumn{8}{|c|}{$\begin{array}{l}1 \text { Total number of species }=53 \text { for all years } \\
2 \text { List of all } 15 \text { families represented in the analysis in approximate order of numerical abundance: Pomadasysidae, } \\
\text { Holocentridae, Serranidae, Acanthuridae, Labridae, Scaridae, Pomacentridae, Chaetodontidae, Apogonidae, Muraenidae, } \\
\text { Clinidae, Cirrhitidae, Tetraodontidae Canthigasteridae, Balistidae. See text for families and species omitted } \\
{ }^{3} \mathrm{~J}^{\prime}=\frac{\mathrm{H}^{\prime}}{\mathrm{H}^{\prime} \mathrm{max}}=\frac{\mathrm{H}^{\prime}}{\log _{2} \mathrm{~S}} \\
{ }^{4} \text { Turnover }\left(\mathrm{T}_{\mathrm{ov}}\right)=1 / 2\left(\frac{\mathrm{d}}{\mathrm{n}_{\mathrm{j}}}+\frac{\mathrm{g}}{\mathrm{n}_{\mathrm{k}}}\right) \times 100 ; \mathrm{d}=\# \text { of species lost; } \mathrm{g}=\text { \# species gained; } \mathrm{n}_{\mathrm{j}}=\# \text { species in earlier census; } \\
\mathrm{n}_{\mathrm{k}} \text { \# species in later census (Talbot et al., 1978) } \\
5 \% \text { change in total abundance }=\frac{\mathrm{n}_{1}-\mathrm{n}_{\mathrm{j}}}{.5\left(\mathrm{n}_{1}+\right)} \times 100 ; \mathrm{n}_{\mathrm{i}}=\# \text { fish in earlier census; } \mathrm{n}_{\mathrm{j}}=\# \text { fish in later census }\end{array}$} \\
\hline
\end{tabular}

distinguished in the field. The raw data used in our analysis are listed in Appendix 1.

The remaining 53 species for all years are remarkably evenly distributed and species richness varies little from year to year (Table 1). Differences in diversity $\left(\mathrm{H}^{\prime}\right)$ and equitability $\left(\mathrm{J}^{\prime}\right)$ can be accounted for in the highly variable numbers of grunts (Pomadasyidae) which appeared in large numbers on the reef in some years. Holocentrid diversity and abundance was also quite variable. Apogonids were absent in 1962 but present in all subsequent censuses. In 1962 Randall found 6 species of scarids (parrotfishes) and 1 territorial pomacentrid species while in later years this pat-

Table 2. Spearman Rank Correlation Coefficient $\left(\mathrm{r}_{\mathrm{s}}\right)^{1}$ and Coefficient of Community $(\mathrm{CC})^{2}$ for Randall Reef census data

\begin{tabular}{|c|c|c|c|c|}
\hline & 1975 & 1977 & 1978 & 1979 \\
\hline 1962 & $\begin{array}{l}\mathrm{r}_{s}=0.354 \\
(\mathrm{p}<.01) \\
\mathrm{CC}=0.630\end{array}$ & $\begin{array}{l}\mathrm{r}_{\mathrm{s}}=0.428 \\
(\mathrm{p}<.01) \\
\mathrm{CC}=0.522\end{array}$ & $\begin{array}{l}\mathrm{r}_{\mathrm{s}}=0.400 \\
(\mathrm{p}<.01) \\
\mathrm{CC}=0.511\end{array}$ & $\begin{array}{l}I_{s}=0.326 \\
(p<.01) \\
C C=0.549\end{array}$ \\
\hline 1975 & & $\begin{array}{l}\mathrm{r}_{\mathrm{s}}=0.415 \\
(\mathrm{p}<.01) \\
\mathrm{CC}=0.675\end{array}$ & $\begin{array}{l}\mathrm{r}_{\mathrm{s}}=0.308 \\
(\mathrm{p}<.01) \\
\mathrm{CC}=0.545\end{array}$ & $\begin{array}{l}I_{s}=0.382 \\
(p<.01) \\
C C=0.617\end{array}$ \\
\hline 1977 & & & $\begin{array}{l}\mathrm{r}_{\mathrm{s}}=0.844 \\
(\mathrm{p}<.01) \\
\mathrm{CC}=0.750\end{array}$ & $\begin{array}{l}r_{5}=0.661 \\
(p<.01) \\
C C=0.614\end{array}$ \\
\hline 1978 & & & & $\begin{array}{l}\mathrm{r}_{5}=0.581 \\
(\mathrm{p}<.01) \\
\mathrm{CC}=0.636\end{array}$ \\
\hline \multicolumn{5}{|c|}{$\begin{array}{l}1 \text { No correction for ties } \mathrm{N}=53 \text {; one-tailed t test } \\
{ }^{2} \mathrm{CC}=\mathrm{N}_{\mathrm{c}} / \mathrm{N}_{\mathrm{j}}+\mathrm{N}_{\mathrm{k}}-\mathrm{N}_{\mathrm{c}} \text { Talbot et al. }(1978) ; \mathrm{N}_{c}= \\
\text { species in common; } \mathrm{N}_{j}=\text { species on reef } j_{i} N_{k}=\text { species } \\
\text { on reef } k\end{array}$} \\
\hline
\end{tabular}

tern was reversed with a maximum of 3 species of scarids and 5 territorial pomacentrid species. Other differences are relatively minor involving the presence or absence of one or two species. As shown in Table 1 the percent turnover in species composition varies from 14 to $23 \%$ while percent change in total abundance varies from 25 to $85 \%$, the extreme value again being caused largely by variable grunt numbers.

Spearman Rank Correlation Coefficients of species densities for all pairs of years appear in Table 2. The censuses are all highly significantly correlated, showing moderate predictability between censuses. Table 2 also shows similarity of the censuses as indexed by Jaccard's Coefficient of Community (Talbot et al. 1978), which indicates the percentage of species a pair of censuses has in common.

\section{DISCUSSION AND CONCLUSIONS}

Randall (1963) described in some detail the species arriving at Randall Reef up to 2 years after its construction. The reef had 35 species present within 2 months of its construction and gained only 6 species in the next 10 months. Most of the species arrived on the reef as post-larvae settling from the plankton or as juveniles arriving from nearby areas.

We found that some of the species (e.g. Haemulon spp.) are present on the reef in transient juvenile populations which probably depend on reproductive cycles which deposit larvae from the plankton. The apogonids did not appear on Randall Reef until after 2 years indicating a longer term for colonization, most likely from the plankton. Other species, probably the majority, arrived as juveniles moving in from the sur- 
rounding grassbeds or nearby reef areas. These have formed stable adult populations which have persisted over the term of the study and constitute the most conspicuous elements on the reef. These species include Holocentrus ascensionsis, Epinephelus guttatus, Alphestes afer, Haemulon plumieri, Holocanthus ciliaris, H. tricolor, Eupomacentrus variabilis, E. partitus, Halichoeres spp., Thalassoma bifasciatum, Sparisoma aurofrenatum, Acanthurus spp., and Canthigaster rostrata (Appendix 1). This persistence does not mean that these populations are static, as the change in total fish abundance between consecutive censuses runs upward of $25 \%$ (Table 1). It is noteworthy that for each pair of consecutive censuses the turnover in species composition is substantially less than the change in fish abundance.

Using small artificial reefs varying in the sizes of available holes, Russell et al. (1974), Molles (1978), and Talbot et al. (1978) found no relationship between reef structure and fish species composition. In contrast to these studies, our data do not allow us to evaluate directly the importance of reef configuration to the fishes colonizing the reef. However, a considerable portion of Randall Reef has disappeared into the sediment over the years, and census data suggest that this had little effect on the composition of fish fauna of the reef. This may indicate that something more than habitat complexity and space are important to fishes inhabiting the reef. Perhaps for some fishes the reef is more a landmark than a source of shelter. Not all of the fishes use the reef for all their activities. The pomadasyids, holocentrids and serranids form resting groups over the reef by day and move into the seagrass bed to feed at night (Ogden and Ehrlich, 1977). It is possible that for other fishes, however, habitat configuration and space may be very important.

Two years after reef construction, there were several scarid species and few pomacentrids while in censuses 13 to 17 years later, we recorded several pomacentrid species and few scarids. This reciprocal relationship may be due to the territoriality of Eupomacentrus species, which are especially aggressive towards scarids (Robertson et al. 1976; Ebersole, 1977). The data suggest that pomacentrids colonize the reef over a long term, and their defense of the substrate may be the factor limiting the diversity of the competing scarids (Appendix 1).

It could be supposed that the high degree of constancy in species richness on Randall Reef is due to a balance between the loss of concrete blocks to the sediment acting to reduce the total number of fish on the reef and consequently reducing the number of species, and the addition of algae, coral, sponges, and other encrusting organisms acting to increase reef fish species richness by increasing the microhabitat diversity on the reef. However, if these were the only forces acting on the structure of the Randall Reef fish community, there would be gross changes in the species composition of the community over time. Our observations show that this is decidedly not the case.

Randall Reef has been populated with basically the same fish community in the second cycle of colonization as in the first. The application of a quantitative index of 'predictability' to our data presents a difficult problem. We are primarily interested in distinguishing between the case where the identities and densities of species in a coral reef fish community are determined randomly and the case where species' identities and abundances are determined by the interactions (predation, mutualism, competition) between them. In the case of random determination of community composition, the identities and densities of the fish species in one year will not be related to those of another year, whereas the influence on community composition of the unvarying interactions between species will produce an association between the identities and abundances of species in any 2 years. Computing correlations between pairs of years discriminates between these two possible cases, since communities assembled randomly will not be significantly correlated. Over 19 years of observation, the fish communities have maintained a highly significant degree of similarity (Table 2), despite removal of predators (moray eels) in 1978, collapse and settling of the reef structure, encrustation of its concrete blocks, and censuses being taken in different months for different years. These results differ substantially from those obtained from artificial reefs by Talbot et al. (1978). The greater instability of the fish fauna of these smaller reefs is indicated by average Coefficients of Community (.322 for reefs constructed in summer, 318 for reefs constructed in winter) less than half of any such values that we obtained (Table 2). Our findings are, however, in agreement with those of Gladfelter et al. (in press) who found a considerable degree of similarity among large-patch reef fish faunas on reefs of similar structure both in St. Croix (U.S. Virgin Islands) and in Enewetak (Marshall Islands). In fact, the Coefficients of Community we calculated for temporally separated censuses of Randall Reef ( $\overline{\mathrm{x}}=.605 \pm .075 \mathrm{SD}$; see Table 2$)$ correspond closely to Coefficients Community calculated from the data generated by Gladfelter et al. for spatially separated sets of reefs with similar structure: low pavement reefs with complex structure in St. Croix $(\overline{\mathrm{x}}=.629 \pm .048 \mathrm{SD})$, Porites reefs on St. Croix $(\overline{\mathrm{x}}=$ $.574 \pm .062 \mathrm{SD})$, and moderately to highly complex shallow reefs on the Enewetak lagoonal shelf $(\bar{x}=.636$ $\pm .054 \mathrm{SD})$. Working with even larger natural reefs in the Gulf of Mexico, Smith (1979) found that 3 years after near-defaunation by red tide of 2 natural reefs, 
the fish community resembled the pre-disaster community so closely as to give Coefficients of Community of .778 and .806 . Given a certain structure and a certain, brief period of colonization on a large reef, it appears that most of the appropriate species will arrive to form a persistent community, the stability of which is indicative of orderly structure. The predictability of the community seems to increase with the size of the reef.

In systems as complex as coral reefs, differences between species may be probabilistic rather than deterministic or absolute. As suggested by Brock et al. (1979) moderately large samples are needed to detect these differences and to perceive the over-all predictability of the community.

It seems likely that the chaotic community structure found by some workers in the Pacific may be a statistical artifact of the small structures - natural and artificial - that they have studied. The important paper of Sale and Dybdahl (1975) exemplifies this problem. These authors studied a reef-flat fish community of 56 species by collecting all fishes from 10 live coral heads and 10 dead coral heads .25 to $1.00 \mathrm{~m}$ in diameter at intervals of 4 months.

Using only data from the 34 most common species, Sale and Dybdahl computed for each collection the dissimilarity in species composition for all possible live-live, dead-dead, and dead-live pairs of coral heads. The authors believed that if niche segregation is characteristic of this community, then the 6 mean dissimilarities computed for live-dead pairs should be greater than the 6 mean dissimilarities computed for live-live pairs and for dead-dead pairs. However, since the average coral head contains only 5.25 fish individuals out of the community subset of 34 species, all comparisons between heads of any type are likely to be very different, and by taking means for each collection date the statistical tests must be performed on rather small samples. It is statistically very unlikely that this methodology would reveal differences in the species compositions of live vs dead coral heads, especially if niche differences are probabilistic. It is not meaningful that statistical analysis reveals no difference between the mean dissimilarities of live-dead pairs and deaddead pairs, especially since the average dead coral head contains only 3.22 fishes. Rather, it is meaningful - and surprising - that the mean dissimilarity of livedead pairs is significantly greater than that of live-live pairs. Sale and Dybdahl dismiss this surprisingly significant difference to conclude that the groups of fishes occupying neighboring units of the same type are but little more similar to each other in faunal composition than are those in $\mathrm{D}$-units (dead heads) to those in L-units (live heads)'. The actual difference in faunal composition between dead coral heads and live coral heads is clearly demonstrated by our application of a chi-square test for heterogeneity, which shows a very highly significant difference between the 2 types of heads $\left(\mathrm{x}^{2}=243.27, \mathrm{p}<0.001\right)$.

Without applying statistics, Sale and Dybdahl examined their data to determine if particular fish species occur exclusively in dead coral heads, and concluded that of the 56 species they collected only 3 prefer live coral heads. Actually, only 15 species are sufficiently abundant ( $N \geqslant 9$ ) for statistical analysis and for some of these species sample size is marginal. The application of the binomial test to these 15 species indicates that 5 prefer live coral heads (all $p<0.001$ ), 5 prefer dead coral heads (all $\mathrm{p}<0.001$ ), and 5 (including the 3 least abundant species) show no preference. Thus, when preference for coral type is considered on a probabilistic basis rather than a deterministic basis, the proportion of species which are viewed as discriminators increases dramatically. In a similar, more recent paper, Sale and Dybdahl (1978) encounter similar analytical problems, which again derive from the probabilistic character of niches and the question of scale.

Clearly, at the scale of individual coral heads, it is at best very difficult to predict what species will be found. But examination of a coral reef fish community at a larger scale, such as on Randall Reef, reveals predictability and apparent order. The idea that processes which are probabilistic on a small scale may sum up to determinism on the large scale is familiar to population biologists. The circumstances of competition, predation, disease and the physico-chemical environment that a single organism will encounter during its life are so uncertain that it is impossible to predict an ideal phenotype for it. But considering for a whole population the probabilities of events that can be experienced, it is possible to derive deterministic selection coefficients that account for particular morphological and behavioral traits. Extensive and detailed studies have revealed niche differences between the taxonomically and ecologically closely related species of several guilds of coral reef fish (e.g. Jones, 1968; Vivien and Peyrot-Clausade, 1973; Clarke, 1977; Luckhurst and Luckhurst, 1978).

The relative stability of coral reef fish communities on a large scale does not mean that they are static. Some change in species concentration over time has been observed in all long-term studies of coral reef fish communities, including our study of Randall Reef. It is also clear that predation and disturbance on the coral reef are constantly opening up new space on the reef in a random way. Armstrong (1976) and Caswell (1978) have shown how 2 species identical in their resource requirements can coexist in such an environment, with the important proviso that the niches of the 2 species differ with respect to colonizing ability such that the 
inferior competitor is the better colonizer. It is likely that predation and disturbance contribute to the high diversity of coral reef fish communities by allowing this type of niche differentiation to occur. Since open space is generated on the reef throughout the year, it is also possible that species of coral reef fish that are identical on most niche dimensions may have segregated niches due to seasonal differences in recruitment (an exploration of this possibility is currently being conducted by Ebersole).

To summarize, we believe that the stochastic features of predation and disturbance play an important role in maintaining the high diversity of coral reef fish communities by creating additional niche dimensions along which segregation can occur. However, our study of Randall Reef, considered in the context of other similar studies, leads us to the conclusion that these stochastic features do not obviate the need for segregation on other niche dimensions (microhabitat, diet, etc.) between some species in some guilds. When the temporal scale and the spatial scale of a study is small, which has been the case in most previous research on coral reef fish communities, niche segregation is hard to detect because of its probabilistic nature and/or because of the stochastic events (predation, disturbance) that underly it. When, as on Randall Reef, temporal and spatial scales are expanded, the probabilities are resolved. A system of considerable predictability and stability is revealed, suggesting an orderly community structure.

Acknowledgements. We thank W. Gladfelter, M. Moese, M. Robblee, M. Shulmann and C. Shipp for assistance in the field. The cooperation of the staff of the Virgin Islands National Park, especially W. Webb (Superintendent), R. Kemple, B. Lamnan, and A. Robinson is appreciated. M. Shulman assisted in data analysis and also provided valuable critical comments. E. Bermingham, R. Clarke, J. Hatch, D. Policansky, M. Rex, N. Wolf, R. Philibosian and J. Yntema read earlier drafts of the paper. We are especially grateful to Dr. Peter Sale for providing access to his raw data for our critical analysis. Portions of this work were supported by National Science Foundation Grant OCE 7909577 (JPE), the Lerner Fund of the American Museum of Natural History (JPE) and the International Decade of Ocean Exploration, Seagrass Ecosystem Study OCE 7601304 (JCO) as well as the West Indies Laboratory. This is Contribution Number 65 of the West Indies Laboratory, Fairleigh Dickinson University, St. Croix, U.S. Virgin Islands.

\section{Appendix I}

Census Data from Randall Reef (number of individuals) ${ }^{1}$ $\begin{array}{lllll}1962 & 1975^{2} & 1977 & 1978 & 1979\end{array}$

\section{MURAENIDAE}

Gymnothorax moringa G. vicinus

$\begin{array}{rrrrr}3 & 3^{*} & 5 & 3 & 2 \\ 4 & 1^{*} & 10 & 12 & 7\end{array}$

$\begin{array}{lllll}1962 & 1975^{2} & 1977 & 1978 & 1979\end{array}$

\section{HOLOCENTRIDAE}

Holocentrus ascensionis

H. rufus

H. marinus

Adioryx coruscus

Myripristis jacobus

SERRANIDAE

Epinephelus guttatus

E. striatus

Cephalopholis fulva

Petrometopon cruentatum

Hypoplectus sp.

Serranus tigrinus

Alphestes afer

APOGONIDAE

Apogon maculatus

A. binotatus

CIRRHITIDAE

Amblycirrhitus pinos

POMADASYIDAE

Haemulon aurolineatum

$H$. chrysargyreum

H. plumieri

H. sciurus

H. flavolineatum

H. melanurum

\section{CHAETODONTIDAE}

Holacanthus ciliaris

H. tricolor

Chaetodon capistratus

C. striatus

POMACENTRIDAE

Eupomacentrus planifrons

E. variabilis

E. partitus

E. mellis

Chromis cyanea

C. multilineata

LABRIDAE

Bodianus rufus

Halichoeres bivittatus

H. radiatus

H. garnoti

H. maculipinna

H. poeyi

Thalassoma bifasciatum

BALISTIDAE

Balistes vetula

SCARIDAE

Sparisoma rubripinne

S. chrysopterum

S. viride

S. aurofrenatum

Scarus croicensis

S. taeniopterus

CLINIDAE ${ }^{3}$

Malacoctenus/Labri-

somus spp.

ACANTHURIDAE

Acanthurus coeruleus

$\begin{array}{rcrrr}59 & 95 & 75 & 35 & 23 \\ - & 25^{\circ} & - & - \\ 1 & - & - & - \\ 4 & 7 & - & - \\ 370 & 15 & - & -\end{array}$

23

5

$\begin{array}{rrrrr}- & - & 5 & 2 & 4 \\ 7 & - & - & - & - \\ - & 4 & 6 & 5 & 3 \\ 18 & 1 & - & - & - \\ 3 & 2 \cdot & 1 & 2 & 4 \\ 6 & 6 \cdot & 3 & 15 & - \\ 65 & 55 & 50 & 160 & 56\end{array}$

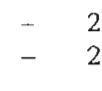

20

2

577

577

1267

27

1

8

1

$-$

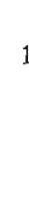

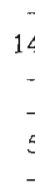

14

$-17$

1 3 4 56 , 


\begin{tabular}{|c|c|c|c|c|c|}
\hline & 1962 & $1975^{2}$ & 1977 & 1978 & 1979 \\
\hline A. bahianus & 14 & $7^{\circ}$ & 10 & 8 & 2 \\
\hline A. chirurgus & 29 & 6 & 2 & 2 & 1 \\
\hline $\begin{array}{l}\text { CANTHIGASTERIDAE } \\
\text { Canthigaster rostrata }\end{array}$ & 5 & $7^{\circ}$ & 4 & 3 & 5 \\
\hline $\begin{array}{l}\text { TETRADONTIDAE } \\
\text { Sphaeroides spengleri }\end{array}$ & 1 & - & - & - & - \\
\hline Total number of species & 39 & 36 & 31 & 32 & 40 \\
\hline Total number of individuals & 2656 & 1070 & 774 & 1048 & 1346 \\
\hline
\end{tabular}

1 See text for species omitted from analysis

2 Census in 1975 was done using abundance categories for some species; numerical value arbitrarily assigned from abundance category to those species marked with an asterisk

${ }^{3}$ Clinids lumped in the analysis

\section{LITERATURE CITED}

Armstrong, R. A. (1976). Fugitive species: experiments with fungi and some theoretical considerations. Ecology 57: 955-963

Brock, R. E., Lewis, C., Wass, R. C. (1979). Stability and structure of a fish community on a coral patch reef in Hawaii. Mar. Biol. 54: 281-292

Caswell, H. (1978). Predator-mediated coexistence: A nonequilibrium model. Am. Nat. 112: 127-154

Clarke, R. D. (1977). Habitat distribution and species diversity of chaetodontid and pomacentrid fishes near Bimini. Bahamas. Mar. Biol. 40: 277-289

Ebersole, J. P. (1977). The adaptive significance of interspecific territoriality in the reef fish Eupomacentrus leucostictus. Ecology 58: 914-920

Gladfelter, W B., Ogden, J. C., Gladfelter, E. H. Similarity and diversity among patch reef fish communities: a comparison between tropical western Atlantic (Virgin Islands) and tropical central Pacific (Marshall Islands) reefs. Ecology, in press

Goldman, B., Talbot, F. H. (1976). Aspects of the ecology of coral reef fishes. In: Jones, O. A., Endean, R. (eds) Biology and geology of coral reefs, Vol. IV. Academic Press, New York, pp. 125-124

Jones, R. S. (1968). Ecological relationships in Hawaiian and Johnston Island Acanthuridae (surgeonfishes). Micronesica 4 : 309-361
Luckhurst, B. E., Luckhurst, K. (1978). Analysis of influence of substrate variables on coral reef fish communities. Mar. Biol. 49: 317-324

Molles, M. C. (1978). Fish species on model and natural reef patches: experimental insular biogeography. Ecol. Monogr 48: 289-306

Ogden, J. C., Ehrlich, P. R. (1977). The behavior of heterotypic resting schools of juvenile grunts (Pomadasyidae). Mar. Biol. 40: 273-280

Randall, J. E. (1963). An analysis of the fish populations of artificial and natural reefs in the Virgin Islands. Carib. J. Sci. 3(1): 1-16

Robertson, D. R., Sweatman, H. P. A., Fletcher, E. A., Cleland, M. G. (1976). Schooling as a mechanism for circumventing the territoriality of competitors. Ecology 57: 1208-1220

Russell, B. C., Talbot, F. H., Domm, S. (1974). Patterns of colonization of artificial reefs by coral reef fishes. In: Proceedings 2nd International Coral Reef Symposium, Vol. 1. The Great Barrier Reef Committee, Brisbane, Australia, pp. 207-215

Sale, P. F. (1975). Patterns of use of space in a guild of territorial reef fishes. Mar. Biol. 29: 89-97

Sale, P. F. (1977). Maintenance of high diversity in coral reef fish communities. Am. Nat. 111: 337-359

Sale, P. F., Dybdahl, R. (1975). Determinants of community structure for coral reef fishes in an experimental habitat. Ecology 56: 1343-1355

Sale, P. F., Dybdahl, R. (1978). Determinants of community structure for coral reef fishes in isolated coral heads at lagoonal and reef slope sites. Oecologia 34: $57-74$

Smith, C. L. (1973). Small rotenone stations: a tool for studying coral reef fish communities. Am. Mus. Nov. 2512, 1-21

Smith, C. L., Tyler, J. C. (1972). In: Collette, B. B., Earle, S. A. (eds) Results of the Tektite program, ecology of coral reef fishes. Los Angeles County Museum Sci. Bull. 14: 125-170

Smith, C. L., Tyler, J. C. (1975). Succession and stability in fish communities on dome-shaped patch reefs in the West Indies. Am. Mus. Nov. 2572: 1-18

Smith, G. B. (1979). Relationship of eastern Gulf of Mexico reef-fish communities to the species equilibrium theory of insular biogeography. J. Biogeog. 6: 49-61

Talbot, F. H., Russell, B. C., Anderson, G. R. V (1978). Coral reef fish communities: unstable, high-diversity systems? Ecol. Monogr 48: 425-440

Vivien, M. L., Peyrot-Clausade, M. Comparative study of the feeding behavior of three coral reef fishes (Holocentridae), with special reference to the Polychaeta of the reef cryptofauna as prey. In: Proceedings 2nd International Coral Reef Symposium, Vol. 1. The Great Barrier Reef Committee, Brisbane, Australia, pp. 179-192 